\title{
Metal adsorption in aqueous media using Moringa oleifera Lam. seeds produced in Ecuador as an alternative method for water treatment
}

\section{Andrea C. Landázuri, , Jaime D. Cahuasquí, Andrés S. Lagos}

${ }^{1}$ Universidad San Francisco de Quito USFQ, College of Science and Engineering, , Chemical Engineering Department; -Engineering, Applied Sciences \& Simulation Group (GICAS), Calle Diego de Robles y Vía Interoceánica, Campus Cumbayá, Edif. Maxwell. ZIP Code 17-1200-841, Quito, Ecuador

*Autor para correspondencia/Corresponding author, e-mail: alandazuri@usfa.edu.ec

\section{Adsorción de metales en medio acuoso mediante semillas de Moringa oleifera Lam. producidas en Ecuador como método alternativo de tratamiento de aguas}

\begin{abstract}
This work explores the technical viability in the use of Moringa oleifera Lam. seeds produced in Ecuador as an adsorbent medium for copper (Cu), nickel (Ni) and chromium (Cr) present in water. The seeds were prepared following a sequence of washing, drying, crushing, sieving, rewashing, and final drying. Two treatments were performed based on particle size. Treatment 1 consisted on a mixture of $70 \%$ of particles larger than $2 \mathrm{~mm}$ and $30 \%$ of particles between 1 and $2 \mathrm{~mm}$; while Treatment 2 consisted only on 1 - $2 \mathrm{~mm}$ particles. Batch experiments were performed with metal concentrations ranging from 10 to $150 \mathrm{ppm}$, a dose of $1.00 \mathrm{~g}$ of $\mathrm{MO}$ per liter, and mechanical stirring for 1 hour. Treatment 2 showed to be more favorable to metal removal and the Langmuir model better characterized adsorption of the three metals. The best kinetic description of the three metals is that of a pseudo first-order reaction where the adsorption capacities are $50.93 \mathrm{mg} \mathrm{Cu} / \mathrm{g} \mathrm{MO}, 30.14 \mathrm{mg} \mathrm{Ni} / \mathrm{g} \mathrm{MO}$, and $40.98 \mathrm{mg} \mathrm{Cr} / \mathrm{g} \mathrm{MO}$, with removal percentage of $37-53 \%, 39-76 \%$, and $11-33 \%$, respectively.
\end{abstract}

Keywords. Moringa oleifera, isotherms, adsorption kinetics, metals, water treatment

Editado por/

Edited by:

Diego F. Cisneros -

Heredia

Recibido /

Received:

2016/11/17

Aceptado /

Accepted:

2018/07/13

Publicado en línea / Published online:

2019/03/19

\section{Resumen}

Este trabajo presenta la viabilidad técnica de la utilización de semillas de moringa oleifera (MO) como medio adsorbente de cobre (Cu), níquel (Ni) y cromo ( $\mathrm{Cr}$ ) presente en agua. Las semillas siguieron un proceso de lavado, secado, triturado, tamizado, segundo lavado y secado final. Dos tratamientos en función de proporciones de tamaño de partículas fueron analizados. El primer tratamiento consistió en una mezcla del $70 \%$ de partículas con diámetros mayores a $2 \mathrm{~mm}$ y $30 \%$ de partículas con diámetros entre 1 y $2 \mathrm{~mm}$; mientras que el segundo tratamiento consistió en partículas con tamaños entre 1 y $2 \mathrm{~mm}$ solamente. Soluciones de agua artificial de cada metal fueron preparadas 
con concentraciones de10 a 150 ppm y una dosificación de $1.00 \mathrm{~g}$ de MO fue añadida a cada litro de solución con un tiempo de agitación de 1 hora. El segundo tratamiento demostró ser más favorable a la remoción de metales. El modelo de Langmuir caracterizó la adsorción de los tres metales. La cinética que mejor describe la adsorción de los tres metales es de pseudo primer orden. Las capacidades de adsorción resultantes fueron: $50.93 \mathrm{mg} \mathrm{Cu} / \mathrm{g} \mathrm{MO}, 30.14 \mathrm{mg} \mathrm{Ni} / \mathrm{g} \mathrm{MO}$, y $40.98 \mathrm{mg} \mathrm{Cr} / \mathrm{g} \mathrm{MO}$, mientras que los rangos de remoción obtenidos fueron de 37 - $53 \%, 39-76 \%$, and 11 - 33\%, respectivamente.

Palabras clave. Moringa oleifera, isotermas, cinética de adsorción, metales, tratamiento de agua

\section{INTRODUCTION}

Industrial discharges, material degradation and anthropogenic activities are important sources of metal contamination in water bodies [1-4]. Since metallic contaminants tend to persist and accumulate in the food chain, they constitute a threat to human beings, animals and the surroundings. In order for these metals to be removed, a proper method of sequestration should be applied [2]. Traditional methods are based on adsorbing these contaminants on cationic compounds (such as aluminum sulfate) which are expensive and, sometimes, present deleterious effects in human health [5]. Therefore, a search for substitutes of these compounds and/or new technologies for metal removal in drinking water and wastewater treatment has directed the attention to new environmentally friendly technologies like Biosorption. Since this technique is easily adapted to the drinking water and wastewater treatment plants, it is thought to be the best option for a cost-effective solution.

Biosorption is a specific type of adsorption, characterized by the removal of contaminants (i.e. heavy metals in aqueous solution) by biological material through different mechanisms [3]. The process involves a solid phase, the bioadsorbent, and a liquid phase which contains the pollutant that need to be removed [4]. Bioadsorbent is the name given to any biological material possessing properties that confer high retention capabilities of a given pollutant, achieving the reduction of the concentration in the solution to a level of parts per billion [6].

In Ecuador, the advances in water resource recovery are very limited. For example, only $1 \%$ of wastewater is treated and it is discharged directly to water bodies. The first water resource recovery facility (WRRF) in the Quito Metropolitan District (the capital of Ecuador) started operation in March, 2017. This facility with wide coverage over the southern part of the city is an important milestone. Nevertheless, this plant is still insufficient to cover the needs of wastewater treatment of the city. Due to the high cost of chemicals for its operation, our research group is searching for a cost-effective alternative for future implementation at a pilot and real scale level. 
Moringa oleifera Lam. (MO) from the Moringaceae family [6], depicted in Figure 1, is a crop native to South Asia that grows in the Himalayan foothills and is widely cultivated across the tropics and subtropics [7]. The leafs, seeds and pods are characterized by having good adsorptive properties and can be used as natural coagulants and flocculants, as well as filtration medium in water treatment [5,8-10]. Several studies [1,5,8,11-13]show that $\mathrm{MO}$ pods can remove organic pollutants and pesticides. $\mathrm{MO}$ seeds have good coagulant properties and are capable of removing organic and mineral particulates as well as heavy metals like lead, copper, cadmium, chromium and arsenic from water. Seed extracts have also antimicrobial properties [12]. Therefore, MO has become an environmental alternative to commonly used reagents (aluminum and ferric sulfate, and polymers) used in drinking and wastewater treatment $[11,14,15]$ which have been proven to be more expensive than natural sorbents [1]. Depending on the soil conditions and other environmental variables, $\mathrm{MO}$ shows different chemical and nutrient compositions [12] that can affect its adsorptive, flocculant, coagulant and antimicrobial properties.

Figure 1. Moringa oleifera a) seeds, b) pods. Photographies taken by Jaime Cahuasquí.
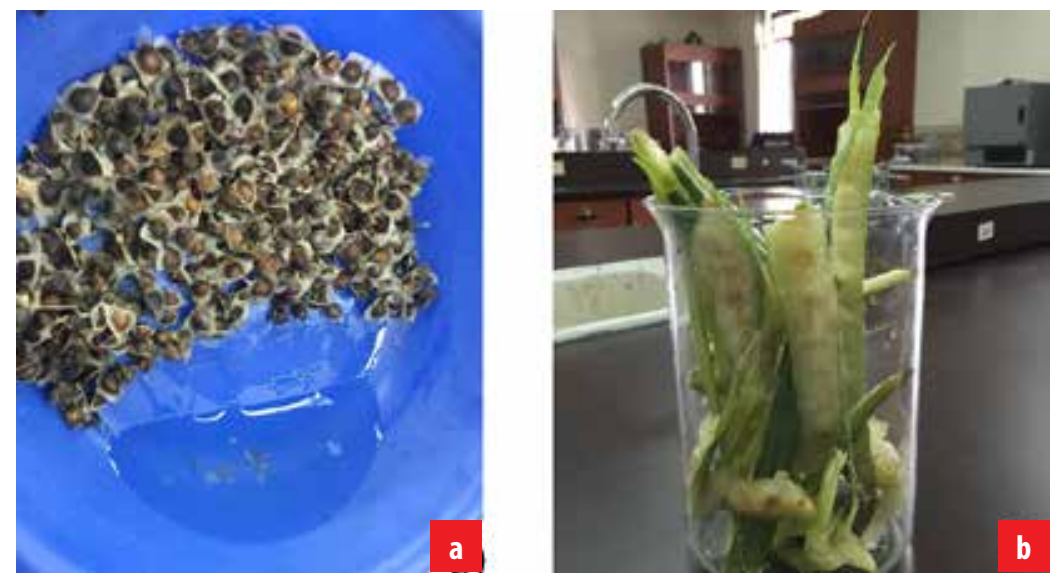

In Ecuador, MO plantations exist in regions such as Santa Elena Peninsula and PedernalesManabí and is currently used for medicinal and dietary purposes [16,17]. Consequently, due to $\mathrm{MO}$ morphological characteristics and adsorption properties $[1,5,8,12]$, it can be presented as a potential metal adsorbent substitute for chemicals used in drinking water and wastewater facilities in the Quito Metropolitan District, Ecuador. For this purpose, this research aims to evaluate the capability of $\mathrm{MO}$ produced in Ecuador to be used as metal adsorbent in water treatment applications.

The objectives of the present research involve: i) the use of Moringa oleifera produced in Ecuador (EMO) as an adsorbent medium, ii) the quantification of EMO effectivity in terms of copper, nickel and chromium removal, and iii) the gain of insightful information regarding the influence of EMO dose and particle size in metal adsorption capacity. Ongoing projects are being executed by our research group to explore the viability of EMO as coagulant, flocculant and filtering medium to remove suspended solids, turbidity, E. Coli, emerging contaminants, among other classic contaminants. 


\section{MATERIALS AND METHODS}

\section{Preparation of EMO}

EMO seeds (Figure 1a) were collected and provided by Ecuamoringa (Guayaquil, EC090510, Ecuador). After reception, seeds were conditioned through six sequential steps: first washing, first drying, crushing, sieving, second washing, and final drying. Distilled water was used throughout washing operations. During the first stage of washing, dust and surface impurities were removed. Then, samples were allowed to dry at room temperature for 24 hours in a shadow area inside the laboratory. The first drying process was performed in an oven at $115^{\circ} \mathrm{C}$ for 24 hours to remove volatile contaminants present in the seeds. A porcelain mortar was used to crush the EMO seeds and two samples were selected based on particle sizes. The first sample (Treatment 1) consisted of $70 \%$ of particles $\geq 2 \mathrm{~mm}$ in diameter, and $30 \%$ of particles $1-2 \mathrm{~mm}$. During the initial stage of the project the most abundant fractions after the seeds were crushed in a mortar fell into these mesh sizes. The minor fraction (30\%) passed the 2-mm sieve and was retained in the 1-mm sieve, while the larger fraction (70\%) was retained in the 2-mm sieve. Treatment 1 consisted on the combination of these two fractions, and, in order to gain insight about particle size effects, Treatment 2 experiments used 100\% of particles with diameters between 1 and $2 \mathrm{~mm}$. The second washing cycle involved using distilled water until the water became clear. Finally, second drying was performed at $115^{\circ} \mathrm{C}$ for 24 hours.

\section{Preparation of the metal containing solutions}

Concentrated solutions containing 1000 ppm of copper (Cu) and nickel (Ni) were prepared by adding $3.925 \mathrm{~g}$ of $\mathrm{CuSO}_{4} \cdot 5 \mathrm{H}_{2} \mathrm{O}$ and $4.050 \mathrm{~g}$ of $\mathrm{NiCl}_{2} \cdot 6 \mathrm{H}_{2} \mathrm{O}$ to one liter of distilled water, respectively (Reagents HVO, Quito, Ecuador). Subsequently, a series of aqueous solutions with different concentrations of metals in the range of 10 to $150 \mathrm{ppm}$ were prepared from the concentrated solutions. Regarding chromium (Cr), a 1000 ppm standard with 2\% nitric acid AA13N-1 (AccusTrace, New Haven, CT 06513 USA) was used to prepare the solutions.

\section{Adsorption experiments}

In order to determine the effectiveness of the adsorbent and to understand the dynamics of the process, an investigation of isothermal adsorption can be performed. For this, two laboratory techniques could be used: batch (discontinuous process) and column (continuous process) experiments [18]. The batch method consists in applying constant agitation for different concentrations of the contaminant to study specific adsorbent doses. The adsorption capacity $q_{e}$ (mg metal ions adsorbed / $\mathrm{g}$ of adsorbent) is related to the equilibrium concentration of metal ions $C_{e}$ (mg metal ions in the solution / $\mathrm{L}$ solution) [19] and this relationship is described by Equation 1:

$$
q_{e}=K_{m} C_{e}
$$

where $K_{m}$ is the adsorption constant, or distribution coefficient, and the adsorption equilibrium capacity, $q_{e}$ is given by Equation 2: 


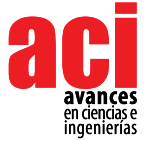

$$
q_{e}=\frac{C_{0}-C_{e}}{\frac{m}{V}}
$$

where $C_{0}$ is the initial concentration of metal ions in aqueous solution $(\mathrm{mg} / \mathrm{L}), m$ is the amount of dry adsorbent $(\mathrm{g})$ and $V$ is the volume of the aqueous solution (L).

The most widely used models describing adsorption mechanisms based on equilibrium relationships, adsorption kinetics, initial conditions, balance mass and energy of contaminants are [11]nickel, chromium and zinc ions from synthetic waste water by using Moringa aptera Gaertn (MAG: Langmuir [20], [21], Freundlich [22], [23] Temkin [24], [25] and Dubinin-Radushkevich [26], [27] which are explained briefly in the following sections.

\section{Langmuir}

This model describes a monomolecular adsorption without interaction between the adsorbed molecules with a finite number of active centers with the same energy [28]. This model is represented by Equation 3 [11]nickel, chromium and zinc ions from synthetic waste water by using Moringa aptera Gaertn (MAG:

$$
q_{e}=\frac{q_{m} b_{o} C_{e}}{1+b_{0} C_{e}}
$$

where $q_{m}$ is the maximum adsorption capacity (mg of metal / $g$ of adsorbent ion), $b$ is the Langmuir constant ( $L$ solution / $\mathrm{mg}$ of metal ions), $C_{e}$ is the equilibrium concentration of the dilution (mg ion metal in the solution / $L$ solution).

\section{Freundlich}

The Freundlich model represents the relationship between a non-ideal and reversible adsorption [29]. It is applied to heterogeneous surfaces with interaction between the adsorbed molecules (multilayer). This model is described by Equation 4 [1 1]nickel, chromium and zinc ions from synthetic waste water by using Moringa aptera Gaertn (MAG):

$$
q_{e}=K_{f} C_{e}^{\frac{1}{n}}
$$

where $K_{f}$ (mg metal / $g$ of solution ions) and $n$ (dimensionless) are constants dependent upon the adsorbate and adsorbent at a particular temperature.

\section{Temkin}

This model is similar to the Langmuir model, but adds an adsorption energy condition which decreases linearly with increasing surface area of the adsorbent $[24,25,30]$. This model is represented by Equation 5 [11]nickel, chromium and zinc ions from synthetic waste water by using (MAG):

$$
q_{e}=\frac{R T}{b_{t}} \ln \left(K_{t} C_{e}\right)
$$


where $K_{t}$ is the Temkin constant ( $L$ solution / $g$ of adsorbent), $R$ is the ideal gas constant $(8.314 \mathrm{~J} / \mathrm{mol} \mathrm{K})$ and $b_{t}$ is a constant related to the heat of sorption $(\mathrm{J} / \mathrm{mol})$.

\section{Dubinin-Radushkevich}

This model proposes the theory of the volume filling of micropores (TVFM), being the micropores the most significant structures playing a role in adsorption, and it is based on the potential theory of adsorption introduced by Eucken and Polanyi [26,27,30-33]. This model is represented by Equation 6 [11]:

$$
q_{e}=q_{m} e^{-K\left[R T \ln \left(1+\frac{1}{C_{e}}\right)\right]^{2}}
$$

where $K$ is the constant of Dubinin-Radushkevich related to energy adsorption.

\section{First and second order kinetics}

The first order adsorption kinetics in a batch process involves assigning an active center for each metal ion, while the second-order kinetics involves two active centers for each metal ion [34]. These relationships can be represented by Equations 7 and 8, respectively [11]:

$$
\begin{gathered}
q_{t}=q_{e}\left[1-e^{-k_{1} t}\right] \\
q_{t}=\frac{k_{2} q_{e}^{2} t}{1+k_{2} q_{e} t}
\end{gathered}
$$

where $q_{t}$ is the adsorption capacity according to the time, $k_{1}$ and $k_{2}$ are first and second order adsorption kinetic constants, respectively.

\section{Isotherms}

A batch process with continuous stirring was selected to study the adsorption capacity of EMO with respect to the metal ion concentration in equilibrium. The contact time for each solution (experiment) was set to 60 minutes, with a dose of $1.00 \mathrm{~g}$ of EMO per liter of solution.

\section{Effects of EMO dose}

The procedure explained previously was repeated, but different doses of adsorbent were selected: $0.25 \mathrm{~g}, 0.50 \mathrm{~g}$ and $1.00 \mathrm{~g}$ of EMO, to evaluate the adsorption capacity and determine whether this variation influenced the adsorption affinity already described.

\section{Kinetics}

Adsorption capacity studies with respect to time were executed to identify the behavior of metal adsorption dynamics. For this, ten experiments were performed over 100 ppm metal solutions $(1 \mathrm{~L}$ ) with $1.00 \mathrm{~g}$ of EMO at different contact time intervals.

In each experiment, $10.0 \mathrm{~mL}$ aliquots were taken for subsequent analyses in an atomic absorption spectrometer (AAS). All experiments were performed in triplicate. 


\section{Analysis}

The treated samples were analyzed with a Buck Scientific Atomic Absorption Spectrometer VGP 210 Model (BUCK SCIENTIFIC, East Norwalk, CT 06855, USA). An air/ acetylene flame and single-element hollow cathode lamps were used: $\mathrm{Ni}, \mathrm{Cr}$ and $\mathrm{Cu}$ (BUCK SCIENTIFIC, East Norwalk, CT 06855, USA). The linear dynamic range according to the manufacturer for $\mathrm{Cu}, \mathrm{Ni}$ and $\mathrm{Cr}$ are: 0.005-5 ppm, 0.2-4 ppm and 0.04-5 ppm, respectively.

\section{Statistical Analysis}

Cftool from Matlab ${ }^{\oplus}$ was used for obtaining the respective model parameters and determination coefficients. Other statistics such as the adjusted $R^{2}$ value, SSE and RMSE were also provided by Cftool and can be found as Supplementary Data.

\section{RESULTS}

\section{Adsorption isotherms}

The objective of obtaining the equilibrium concentration $\left(C_{e}\right)$ was to calculate the adsorption capacity $\left(q_{e}\right)$ from Equation 2 to further express it in terms of the isotherm models already described and obtain the best correlation to the equilibrium curves.

\section{Treatment 1}

The model that best represent experimental metal adsorption was Langmuir for all three cases: $\mathrm{Ni}, \mathrm{Cu}$ and $\mathrm{C}$, as observed in Table 1. with coefficients of determination, $\mathrm{R}^{2}$, of $0.9769,0.9982$ and 0.9782 , respectively. For comparison purposes, the $\mathrm{R}^{2}$ statistic is being shown throughout this work as it has been presented in similar studies [5]. The models predict the maximum adsorption capacity $\left(q_{m}\right)$, where Cu proved to be more easily adsorbed $\left(q_{m}=88.68 \mathrm{mg}\right.$ of metal ions $/ \mathrm{g}$ of EMO). The removal percentage reached for Cu was 39\%, while for $\mathrm{Ni}$ and $\mathrm{Cr}$, a removal of $23 \%$ and $7 \%$, were respectively achieved. Figure 2 shows the correlation of experimental data to isotherm models already mentioned, as described in Table 1. The cell with the highest $\mathrm{R}^{2}$ has been colored representing the best fit of experimental data to the proposed models.

Table 1. Model parameters - Treatment 1. The best model is represented by a colored cell based on the highest coefficient of determination, $R^{2}$.

\begin{tabular}{|c|c|c|c|c|c|c|c|c|c|c|c|c|c|c|}
\hline \multirow{3}{*}{ Metal } & \multicolumn{14}{|c|}{ Adsorption isotherms } \\
\hline & \multicolumn{3}{|c|}{ Langmuir } & \multicolumn{3}{|c|}{ Freundlich } & \multicolumn{5}{|c|}{ Temkin } & \multicolumn{3}{|c|}{ Dubinin-Radushkevich } \\
\hline & $q_{m}$ & $b_{0}$ & $R^{2}$ & $K_{f}$ & $n$ & $R^{2}$ & $R$ & $T$ & $K_{t}$ & $b_{t}$ & $R^{2}$ & $K$ & $q_{m}$ & $R^{2}$ \\
\hline $\mathrm{Ni}$ & 25.795 & 0.1500 & 0.9769 & 5.425 & 2.686 & 0.8035 & 8.1344 & 298.15 & 1.7010 & 485.5 & 0.9034 & $2.875 \times 10-6$ & 21.790 & 0.6151 \\
\hline $\mathrm{Cu}$ & 148.375 & 0.0044 & 0.9982 & 1.011 & 1.199 & 0.9983 & 8.1344 & 298.15 & 0.1093 & 154.6 & 0.9640 & $4.805 \times 10-5$ & 28.760 & 0.8706 \\
\hline $\mathrm{Cr}$ & 26.282 & 0.1151 & 0.9802 & 6.435 & 3.175 & 0.8527 & 8.1344 & 298.15 & 1.513 & 484.8 & 0.8963 & $6.349 \times 10-6$ & 22.32 & 0.9632 \\
\hline
\end{tabular}


Figure 2. Treatment 1 - adsorption isotherms for a) $\mathrm{Cu}, \mathrm{b}) \mathrm{Ni}$ and c) $\mathrm{Cr}$. A dose of $1.00 \mathrm{~g} \mathrm{M0}$ into a $1 \mathrm{~L}$ solution, and a contact time of $1 \mathrm{~h}$ were used in each experiment. The best model is represented by a solid line. d) Presents a comparison of the three metals. The adsorption isotherm of $\mathrm{Cr}$ shown in Figure $2 \mathrm{c}$ used a different vertical axis scale to better visualize adsorption behavior.
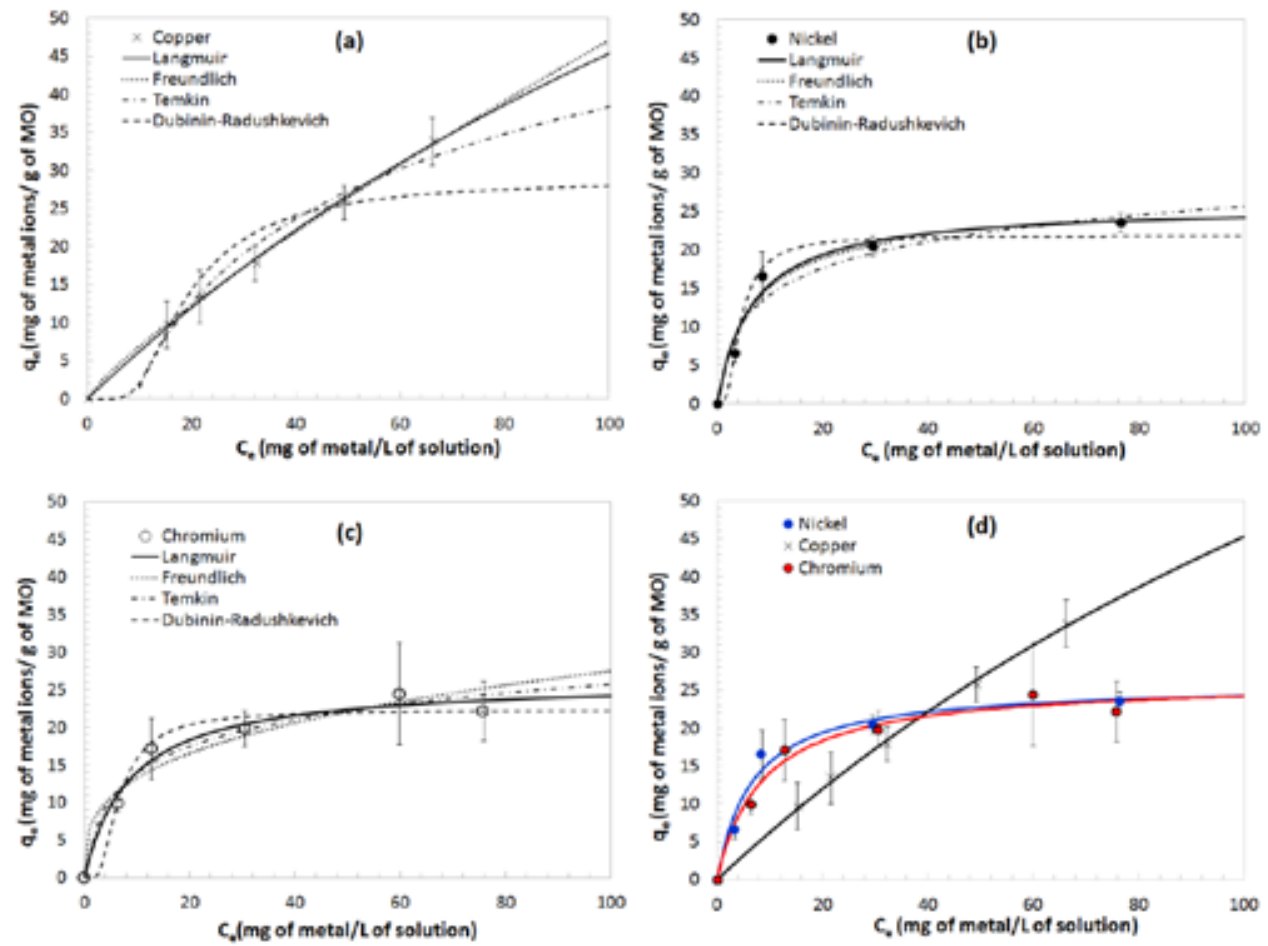

\section{Treatment 2}

Similarly, for Treatment 2, Table 2 shows the model parameters obtained by fitting experimental data to the isotherm models. It can be observed that the experimental data of $\mathrm{Cu}$ and $\mathrm{Ni}$ maintain the previous models with $\mathrm{R}^{2}$ values equal to 0.985 and 0.976, respectively. In contrast, Cu experimental data was found to be best described by Langmuir with an $\mathrm{R}^{2}=0.986$. Figure 3 presents a graphical representation of these results, as well as a comparison between metals. Average percentage removals are 69\% and $55 \%$ for $\mathrm{Ni}$ and $\mathrm{Cu}$, while for $\mathrm{Cr}$ the average removal percentage is 31\%. 
Figure 3. Treatment 2 - adsorption isotherms for a) $\mathrm{Cu}, \mathrm{b}) \mathrm{Ni}$ and c) $\mathrm{Cr}$. A dose of $1.00 \mathrm{~g} \mathrm{MO}$ into a $1 \mathrm{~L}$ solution, and a contact time of $1 \mathrm{~h}$ were used in each experiment. The best model is represented by a solid line. d) Presents a comparison of the three metals.
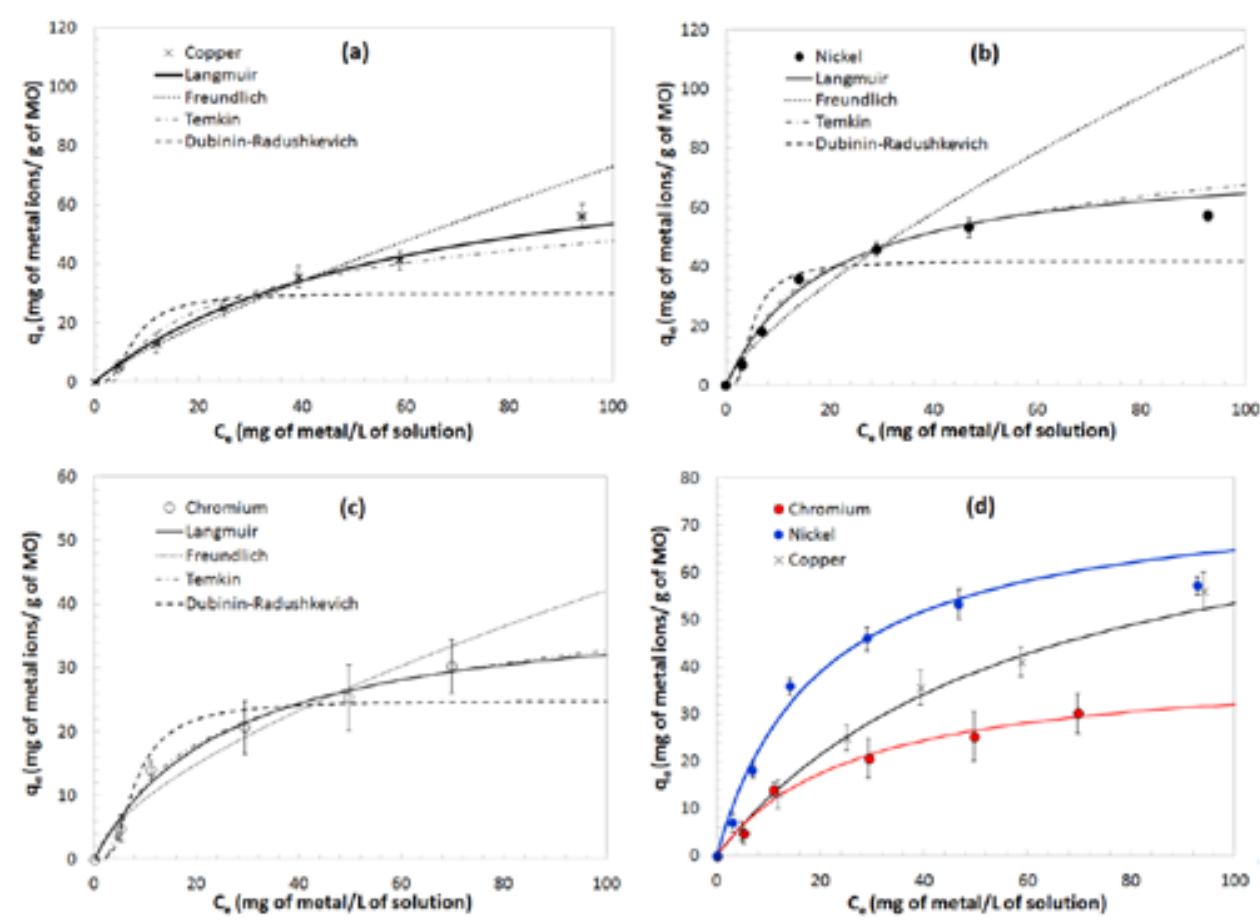

Table 2. Model parameters - Treatment 2. The best model is represented by a colored cell based on the highest Adsorbent dose coefficient of determination, $R^{2}$.

\begin{tabular}{|c|c|c|c|c|c|c|c|c|c|c|c|c|c|c|}
\hline \multirow{3}{*}{ Metal } & \multicolumn{14}{|c|}{ Adsorption isotherms } \\
\hline & \multicolumn{3}{|c|}{ Langmuir } & \multicolumn{3}{|c|}{ Freundlich } & \multicolumn{5}{|c|}{ Temkin } & \multicolumn{3}{|c|}{$\begin{array}{c}\text { Dubinin- } \\
\text { Radushkevich }\end{array}$} \\
\hline & $q_{m}$ & $b_{0}$ & $R^{2}$ & $K_{f}$ & $n$ & $R^{2}$ & $R$ & $T$ & $K_{t}$ & $b_{t}$ & $R^{2}$ & $K$ & $q_{m}$ & $R^{2}$ \\
\hline $\mathrm{Ni}$ & 77.546 & 0.0503 & 0.9873 & 3.817 & 1.353 & 0.9329 & 8.1344 & 298.15 & 0.4741 & 141.6 & 0.9897 & $3.785 \times 10-6$ & 42.01 & 0.9079 \\
\hline $\mathrm{Cu}$ & 85.680 & 0.0166 & 0.9954 & 1.607 & 1.207 & 0.9870 & 8.1344 & 298.15 & 0.2591 & 168.9 & 0.9702 & $7.843 \times 10-6$ & 30.12 & 0.8491 \\
\hline $\mathrm{Cr}$ & 40.528 & 0.0379 & 0.9855 & 2.172 & 1.553 & 0.9123 & 8.1344 & 298.15 & 0.3578 & 271.0 & 0.9868 & $8.632 \times 10-6$ & 24.83 & 0.9575 \\
\hline
\end{tabular}

For the second stage of the study, Treatment 2 was used due to higher removal efficiencies preserving 1-hour contact time and $1 \mathrm{~L}$ of batch volume. Figure 4 presents the equilibrium concentration as a function of adsorbent dose for different initial metal concentrations. From Figures $4(\mathrm{a}, \mathrm{c})$, for $\mathrm{Cu}$ and $\mathrm{Ni}$, respectively, an increase in equilibrium concentration 
is observed when increasing initial concentrations of metal ions; additionally, there is a notable decrease in equilibrium concentrations when adsorbent dose increases from 0.5 to $1 \mathrm{~g}$. Moreover, at lower initial concentrations (e.g. $10 \mathrm{ppm}$ ) the variability in equilibrium concentrations as a function of $\mathrm{MO}$ dose becomes less evident. Figure $4 \mathrm{e}(\mathrm{Cr})$, shows that there is a decreasing linear relationship between equilibrium concentrations as a function of increasing dose, even at low initial concentrations of metal ions. This implies that doses influence proportionally to the adsorption process of $\mathrm{Cr}$.

Figure 4. Effect of changes in $\mathrm{MO}$ dose on equilibrium concentration of metal ions $\left(\mathrm{C}_{e}\right)$, for a) $\left.\mathrm{Cu}, \mathrm{c}\right) \mathrm{Ni}$ e) $\mathrm{Cr}$, and effect of dose on adsorption equilibrium ( $\left.q_{e}\right)$ for: b) $\left.\left.\mathrm{Cu}, \mathrm{d}\right) \mathrm{Ni}, \mathrm{f}\right) \mathrm{Cr}$. Adsorbent doses of $\mathrm{M0}: 1.00 \mathrm{~g}, 0.50 \mathrm{~g}$ and $0.25 \mathrm{~g}$ in 1 liter of solution and a contact time of 1 hour.

(a)

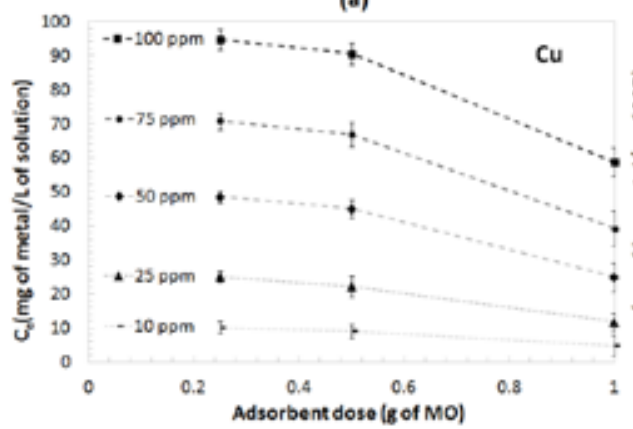

(c)

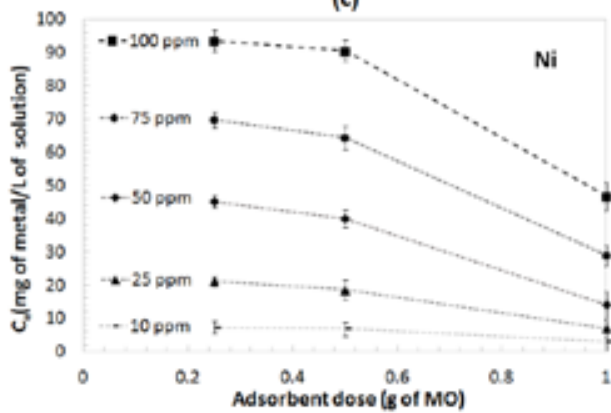

(e)

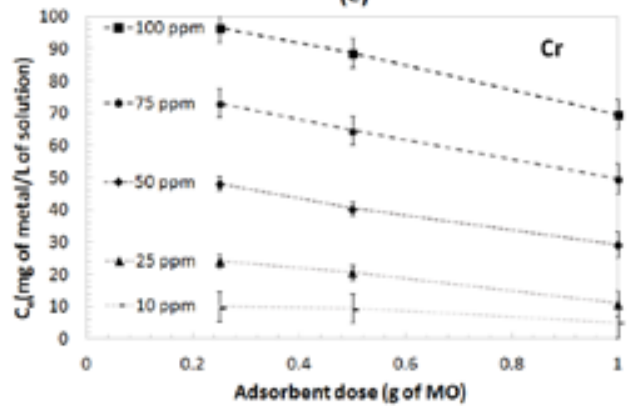

(b)

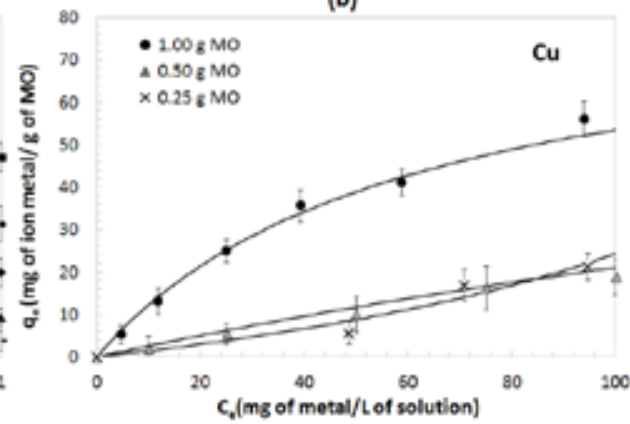

(d)

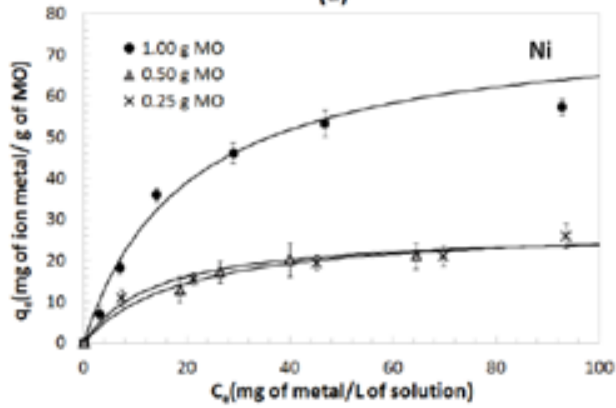

(f)

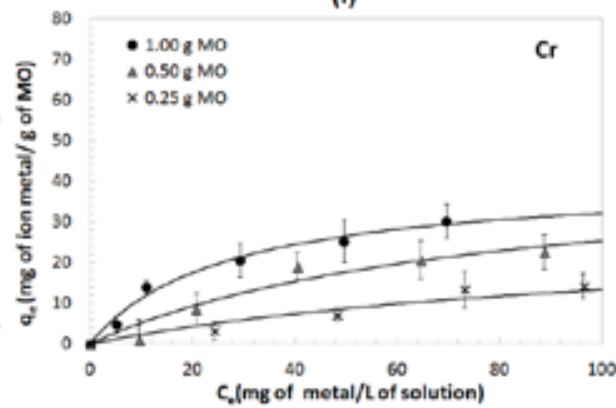

Figure $4 \mathrm{~b}$ represents the adsorbent's dose influence over the adsorption isotherm of $\mathrm{Cu}$; where at high concentrations of $\mathrm{Cu}$, a greater adsorption of $\mathrm{Cu}$ at the equilibrium can be 
found. The adsorption capacity was altered significantly when the dose of $1.00 \mathrm{~g}$ of $\mathrm{MO}$ was reduced to $0.50 \mathrm{~g}$ of MO. Likewise, for $\mathrm{Ni}$ (Figure $4 \mathrm{~d}$ ) the same adsorption behavior is observed. The influence of $\mathrm{MO}$ dose on the adsorption process, especially at high initial concentrations, requires further investigation especially for $\mathrm{Cu}$ and $\mathrm{Ni}$. Figure $4 \mathrm{f}$ shows a proportional variation of $\mathrm{Cr}$ adsorption isotherm regarding to a dose reduction of $\mathrm{MO}$, therefore it is also possible to predict dose's influence in Cr adsorption.

\section{Contact time}

A study of the dynamic behavior of the adsorption capacity $\left(q_{t}\right)$ with respect to time was performed until reaching an adsorption capacity of equilibrium or saturation state $\left(q_{e}\right)$. An initial concentration of $100 \mathrm{ppm}$ of $\mathrm{Cu}, \mathrm{Ni}$ and $\mathrm{Cr}$ and $1.00 \mathrm{~g}$ of $\mathrm{MO}$ (Treatment 2) was established. According to Figure 5, the time for the adsorption capacity ( $q$ ) for $\mathrm{Cu}, \mathrm{Ni}, \mathrm{Cr}$ is 22,18 and $28 \mathrm{~min}$, respectively; being $\mathrm{Ni}$, the metal that required the less contact time to reach a saturation point and greater removal efficiency. The best description of the three metals proved to follow a pseudo-first order kinetics with an $R^{2}>0.97$, implying an active center $\mathrm{MO}$ adsorption for each metal ion.

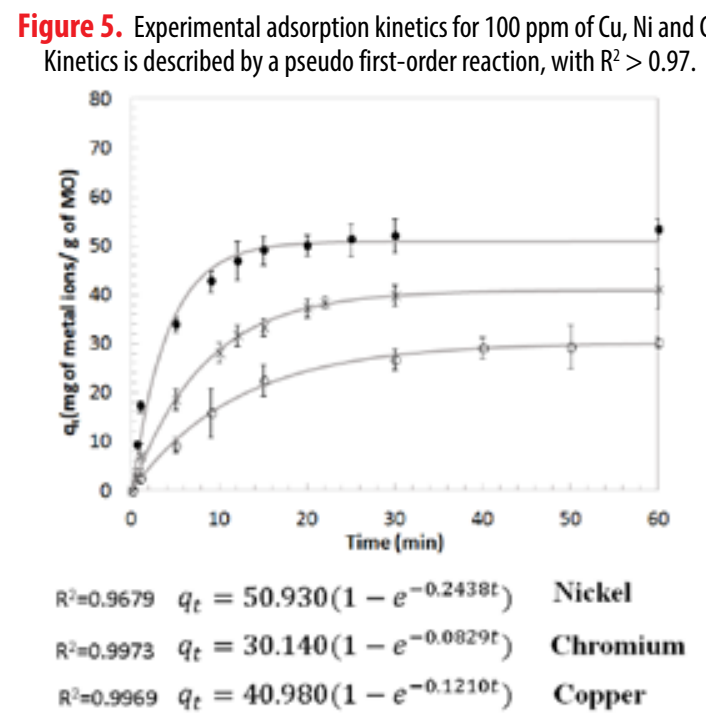

\section{Comparison between metals}

Table 3 focuses on the influence of the $\mathrm{MO}$ dose adjustment with respect to experimental adsorption data (i.e, the conservation of models). This table shows that the variation of $\mathrm{MO}$ dose did not alter the fit of the Langmuir model already identified for $\mathrm{Ni}, \mathrm{Cu}$ and $\mathrm{Cr}$, therefore, it is possible to predict adsorption behavior at lower and higher doses for further implementation in adsorbent systems. 
Table 3. Coefficients of determination $\left(R^{2}\right)$ for the best models characterizing experimental data with varying adsorbent dose (1.0, 0.50 and $0.25 \mathrm{~g} \mathrm{MO} / \mathrm{L})$.

\begin{tabular}{|c|c|c|c|}
\hline & $1.0 \mathrm{~g} \mathrm{MO}$ & $0.50 \mathrm{~g} \mathrm{MO}$ & $0.25 \mathrm{~g} \mathrm{MO}$ \\
\hline $\mathrm{Ni}$ & $\begin{array}{c}\text { 0.9897/0.9873 } \\
\text { Temkin/Langmuir }\end{array}$ & $\begin{array}{l}0.9896 \\
\text { Langmuir }\end{array}$ & $\begin{array}{l}\text { 0.9832/0.9690 } \\
\text { Freundlich/Langmuir }\end{array}$ \\
\hline $\mathrm{Cu}$ & $\begin{array}{l}0.9954 \\
\text { Langmuir }\end{array}$ & $\begin{array}{l}0.9918 \\
\text { Langmuir }\end{array}$ & $\begin{array}{c}\text { 0.9714/0.9437 } \\
\text { Temkin/Langmuir }\end{array}$ \\
\hline $\mathrm{Cr}$ & $\begin{array}{c}\text { 0.9868/0.9855 } \\
\text { Temkin/Langmuir }\end{array}$ & $\begin{array}{c}\text { 0.9664/0.9398 } \\
\text { Temkin/Langmuir }\end{array}$ & $\begin{array}{l}0.9279 \\
\text { Langmuir }\end{array}$ \\
\hline
\end{tabular}

\section{DISCUSSION}

In the case of Treatment 1 , it is presumed that the low $\mathrm{Cr}$ adsorption is influenced by the $\mathrm{pH}$, wherein the initial solution of $\mathrm{Cr}$ has an acid $\mathrm{pH}$ (1.38) which is low compared to the $\mathrm{pH}$ of $\mathrm{Cu}$ (3.54) and $\mathrm{Ni}$ (5.48). A direct comparison is not recommended without having equal $\mathrm{pH}$ values, however it provides insights on the influence of $\mathrm{pH}$ over adsorption since a buffering capacity towards neutral conditions was observed as reported in previous studies [35-37].

In general, the determination coefficients, $R^{2}$, exceeded a value of 0.970 . Nevertheless, the removal of metals using Treatment 1 proved to be less than the removal obtained when Treatment 2 was used. For this reason, the rest of $\mathrm{MO}$ experiments used Treatment 2 for further analyses. It is presumed that better adsorption lies on the use of more homogenous particle sizes (100\% particles had diameters between 1 to $2 \mathrm{~mm}$ ), and also the reduction of particle size allows a greater surface contact area which is essential for maintaining uniform contact during batch processes.

By comparing Figure $2 \mathrm{c}$ and Figure 3c, it appears that when Treatment 2 was used there is a greater adsorption capacity of $\mathrm{Cr}$, while for Treatment 1 the equilibrium concentrations obtained for high initial concentrations (75 ppm onwards) are minimal; and this is another point that argues the importance of homogeneity of particles and their size. Despite the increase in the adsorption capacity $\left(q_{e}\right)$ of $\mathrm{Cr}$, the results in Table 2 indicate that the adsorption capacity of $\mathrm{Cu}$ and $\mathrm{Ni}$ is 1.6 times larger than that of $\mathrm{Cr}$. However further experimentation should be performed in order to fully understand the influence of $\mathrm{pH}$ on the adsorption isotherms and hence the removal efficiencies. Also, it is worth mentioning, as it was already done earlier in this manuscript, that it would not be fair to make a direct comparison based on the results aforementioned since the $\mathrm{pH}$ values were different for each solution.

The methods and results obtained in this work can be compared, in some instances, with some important studies such as Matouq et al. [11] and García-Fayos et al. [13]. For example, Matouq et al., explored $\mathrm{Cr}, \mathrm{Cu}$, Ni and $\mathrm{Zn}$ adsorption using Moringa aptera Gaertn. pods. This work was the base study for the present study, however the present work tested for MO seeds. The paper by García-Fayos et al. [13] evaluates the efficiency of $\mathrm{MO}$ to remove heavy metals in aqueous solutions and similar essays were performed 
in terms of batch experiments, contact time, adsorbent dose, kinetic studies and adsorption isotherms. The selected metals for the analyses were $\mathrm{Cd}$ and $\mathrm{Cu}$. Although the methods could be compared, there are important differences. The present work uses the whole seed, which was then crushed, while the other study used MO husk only which evidenced a 90\% Cu removal. On the other hand, this work determined a Cu removal between 37 and 53\%. García's study correlates to Lagmuir's model for Cu while this work to Freundlich. In addition to this, metal content was determined through FTIR whereas our work used AAS. It is our view that the separation of the husk form the cotyledon is impractical on-site (i.e. in a pilot plant or in a large scale plant).

Overall, the present work suggests working with "more uniform" particle sizes to obtain higher removal percentages. Nonetheless, our research group is working on determining particle size effects on contaminant removal through experimental design to improve the meaningfulness of particle size effect from a statistical point of view [39]. Also, as previously discussed the models presented are $\mathrm{pH}$ specific at initial conditions and there is certainly an influence on adsorption, as it affects the chemistry of solutions of metals, the activity of the functional groups of the adsorbent and competition of metal ions. Working with $\mathrm{Cu}$ and $\mathrm{Ni}$ salts resulted more favorable than working with a chromium standard that included a $2 \%$ nitric acid solution. This is supported by previous studies where an increase in metal adsorption with increasing $\mathrm{pH}$ was evidenced since both the proton and the metal ions compete for the same groups on the surface and thus affecting the surface charge and the overall attraction with the counter ions $[1,37]$.

For perspective, a representative waste water discharge at the Metropolitan District of Quito (Ecuador) has an approximate pH of 5.40 [38], therefore $\mathrm{Cu}$ and $\mathrm{Ni}$ adsorption herein described provides insightful information, although multi-component experiments should be performed to better understand the selectivity of $\mathrm{MO}$ over the selected metals.

At last, a lot of research using Moringa has been performed in other countries, however, this is foreign to Ecuadorian reality. The contribution of this research seek to provide evidence of the adsorption capacity and behavior of metals over Moringa oleifera seeds available in Ecuador for substitution of commonly used chemicals or as a filtration medium.

The key criteria for this work were mainly the initial concentration of the pollutants in aqueous media, the adsorbent dose, particle size and proportions, and contact time. In general, Ni presented higher removal percentage, followed by $\mathrm{Cu}$ and $\mathrm{Cr}$, with $39-76 \%$, $37-53 \%$ and $11-33 \%$ respectively, when MO particles had sized between 1 and $2 \mathrm{~mm}$.

Ongoing research is being held to understand the effects of other parameters that may influence the adsorption capacity of this biological material, such as particle size, $\mathrm{pH}$, and the use of specific sections of $\mathrm{MO}$ seeds, including inner and outer layers and different combinations of those. Furthermore, the washing and drying processes of $\mathrm{MO}$ are being explored and their study is recommended; not only cleaning the surface impurities helps removing the oil from the $\mathrm{MO}$, but freeing the pores is crucial for the adsorption mechanism to take place. A detailed examination using multicomponent water and from real sources is being performed including $\mathrm{Cr}, \mathrm{Cu}$, and $\mathrm{Ni}$, and other metals and metalloids such as $\mathrm{As}, \mathrm{Cd}, \mathrm{Pb}$ and Fe. Also, once $\mathrm{MO}$ has served its purpose as an 
adsorbent medium for metal and contaminant removal, it is important to find methods to regenerate $\mathrm{MO}$ and recover the adsorbed metals. Next, experiments with real water sources will be decisive to propose the adequate contaminant removal technologies. These studies, along with emerging contaminants removal research are promising as it involves the application of new technologies friendly to the environment that could be incorporated into the future wastewater treatment plants in the Metropolitan District of Quito, and in any water, wastewater or industrial plant.

\section{ACKNOWLEDGMENTS}

This research was supported by the 2015 Collaboration Grant of the Universidad San Francisco de Quito-USFQ. Thanks the Programa para la Descontaminación de los Ríos de Quito (i.e. Quito's Rivers Decontamination Program), especially, Dr.-Ing. Luis Antonio Gómez-Avila for supporting these research initiatives for future test and implementation in water resource recovery facility (WRRF) of the Quito Metropolitan District. Thanks to Dr. Egas from the Chemical Engineering Department-USFQ for his feedback and assistance during the development of this project.

\section{AUTHOR'S CONTRIBUTIONS}

This work was conceived by Andrea Landázuri. The funds were acquired and managed by Andrea Landázuri. The experimental methodology was planned by Jaime Cahuasquí and Andrea Landázuri. The experiments were performed by Jaime Cahuasquí and Andrés Lagos. The statistical analysis and curve fitting was executed by Andrea Landázuri. The tables and figures were produced by Andrea Landázuri and Jaime Cahuasquí. The interpretation of data was carried out by all the authors. All authors contributed to the manuscript. 


\section{REFERENCES}

[1] Araújo, C. S., Alves, V. N., Rezende, H. C., Almeida, I. L., de Assunção, R. M., Tarley, C. R., ... \& Coelho, N. M. M. (2010). Characterization and use of Moringa oleifera seeds as biosorbent for removing metal ions from aqueous effluents. Water Science and Technology, 62(9), 2198-2203.

[2] Volesky, B., \& Holan, Z. R. (1995). Biosorption of heavy metals. Biotechnology progress, 11(3), 235-250.

[3] Ahalya, N., Ramachandra, T. V., \& Kanamadi, R. D. (2003). Biosorption of heavy metals. Res. J. Chem. Environ, 7(4), 71-79.

[4] Izquierdo Sanchis, M. (2010). Eliminación de metales pesados en aguas mediante bioadsorción. Evaluación de materiales y modelación del proceso. Universitat de València.

[5] Martín, C., Martín, G., García, A., Fernández, T., Hernández, E., \& Puls, J. (2013). Potenciales aplicaciones de Moringa oleifera. Una revisión crítica. Pastos y Forrajes, 36(2), 137-149.

[6] Volesky, B. (2001). Detoxification of metal-bearing effluents: biosorption for the next century. Hydrometallurgy, 59(23), 203-216.

[7] Food and Agriculture Organization of the United Nations. (2019). Moringa. Recuperado el 3 de julio de 2018 de: http://www.fao.org/traditional-crops/moringa/en/?amp\%3Butm_medium=web\&\%3Butm_ source=faohomepage

[8] Ravikumar, K., \& Sheeja, A. K. (2013). Fluoride removal from water using Moringa oleifera seed coagulation and double filtration. International Journal of Scientific \& Engineering Research, 4(8).

[9] Shan, T. C., Al Matar, M., Makky, E. A., \& Ali, E. N. (2017). The use of Moringa oleifera seed as a natural coagulant for wastewater treatment and heavy metals removal. Applied Water Science, 7(3), 1369-1376.

[10] Landázuri, A.C., et al.(2017). “Ewb-Ecuador/Usfq Project: Contaminant Removal from Effluents through the Use of Moringa Oleifera Seeds for Application in Ecuadorian Rural Communities," in 2017 AlChE Annual Meeting Conference Proceedings.

[11] Matouq, M., Jildeh, N., Qtaishat, M., Hindiyeh, M., \& Al Syouf, M. Q. (2015). The adsorption kinetics and modeling for heavy metals removal from wastewater by Moringa pods. Journal of Environmental Chemical Engineering, 3(2), 775784..

[12] Gopalakrishnan, L., Doriya, K., \& Kumar, D. S. (2016). Moringa oleifera: A review on nutritive importance and its medicinal application. Food Science and Human Wellness, 5(2), 49-56.

[13] Garcia-Fayos, B., Arnal, J. M., Piris, J., \& Sancho, M. (2016). Valorization of Moringa oleifera seed husk as biosorbent: isotherm and kinetics studies to remove cadmium and copper from aqueous solutions. Desalination and Water Treatment, 57(48-49), 23382-23396.

[14] Garcia Fayos, B., ArnalArnal, J., \& Alandia, S. (2012). Estudio de la descontaminación de efluentes líquidos con elevada concentración de metales pesados mediante bioadsorbentes de Moringa oléfera. In Instituto de Seguridad Industrial, Radiofisica y Medioambiental (ISIRYM). Universitat Politécnica de València. XVI Congreso Internacional de Ingeniería de Proyectos Valencia(pp. 11-13).

[15] Cardoso Valverde, K., Ferri Coldebella, P., Fernandes Silva, M., Nishi, L., Carvalho Bongiovani, M., \& Bergamasco, R. (2018). Moringa oleifera Lam. and Its Potential Association with Aluminium Sulphate in the Process of Coagulation/ Flocculation and Sedimentation of Surface Water. International Journal of Chemical Engineering, 2018.

[16] Ecuamoringa.com. (2019). Ecuamoringa - Sembramos vida. Recuperado el 3 de julio de 2018 de: http://www. ecuamoringa.com/

[17] La moringa en Ecuador. (2015, mayo 17). El Universo. Recuperado el 3 de julio de 2018 de: http://www.larevista. ec/orientacion/salud/la-moringa-en-ecuador

[18] Souza, A. F., Câmara, L. D. T., \& Neto, A. J. S. (2011). Modeling of Batch and Continuous Adsorption Systems by Kinetic Mechanisms. In Heat and Mass Transfer-Modeling and Simulation. InTech.

[19] Lo, S. F., Wang, S. Y., Tsai, M. J., \& Lin, L. D. (2012). Adsorption capacity and removal efficiency of heavy metal ions by Moso and Ma bamboo activated carbons. Chemical Engineering Research and Design, 90(9), 1397-1406. 
[20] Langmuir, I. (1916). The constitution and fundamental properties of solids and liquids. Part I. Solids. Journal of the American chemical society, 38(11), 2221-2295.

[21] Langmuir, I. (1918). The adsorption of gases on plane surfaces of glass, mica and platinum. Journal of the American Chemical society, 40(9), 1361-1403.

[22] Freundlich, H.(1926). Colloid and Capillary Chemistry, 3rd ed. London: Methuen

[23] Friendly, H. (1930). Kapillare Chemie, Vol. 1. Leipzig: Akademische Verlagsgesellschaft.

[24] Temkin., M. I. and Phyzhev., W. M. (1940). Acta Physicochim. URSS, vol. 12.

[25] M. M. Dubinin and L. W. Radushkevich, Rend. Acad. Sci. URSS, vol. 55. 1947.

[26] Dubinin, M.M. (1952). Adsorption of gases and vapors and structure of adsorbents. Chemistry Advances, 21 (5), 513.

[27] Liu, S. (2016). Bioprocess Engineering: Kinetics, Sustainability, and Reactor Design. Elsevier.

[28] Chen, X. (2015). Modeling of experimental adsorption isotherm data. Information, 6(1), 14-22.

[29] Eucken., A.(1914).Verhandlungen der Deutschen Physikalischen Gesellschaft, vol. 16.

[30] Dąbrowski, A. (2001). Adsorption — from theory to practice. Advances in colloid and interface science, 93(1-3), 135-224.

[31] Polanyi.,M.(1914).Verhandlungen der Deutschen Physikalischen Gesellschaft, vol. 16.

[32] Polanyi, M. (1916). Adsorption of gases (vapors) by a solid non-volatile adsorbent. Negotiations of the German Physekalische Gesellschaft, 18, 55-80.

[33] Pinzón-Bedoya, M. L., \& Villamizar, L. E. V. (2009). Modelamiento de la cinética de bioadsorción de Cr (III) usando cáscara de naranja. Dyna, 76(160), 95-106.

[34] Aloo, B. N., \& Yator, K. E. (2014). Effects of Moringa oleifera seeds on Escherichia coli, Enterobacter aerogenes, pH, and turbidity in water from selected sources in Kitale town.

[35] Olayemi, A. B., \& Alabi, R. 0. (1994). Studies on traditional water purification using Moringa oleifera seeds. African study monographs, 15(3), 135-142.

[36] Mangale, S. M., Chonde, S. G., Jadhav, A. S., \& Raut, P. D. (2012). Study of Moringa oleifera (drumstick) seed as natural absorbent and antimicrobial agent for river water treatment. J Nat Prod Plant Resour, 2(1), 89-100.

[37] Senthilkumaar, S., Bharathi, S., Nithyanandhi, D., \& Subburam, V. (2000). Biosorption of toxic heavy metals from aqueous solutions. Bioresource Technology, 75(2), 163-165.

[38] Landázuri, A. C., Quevedo, J. L., Torres, M. C., Mayorga, L. F., \& Gómez-Ávila, L. A. (2014). Muestreo y Caracterización de la Descarga "Central Iñaquito", Representativa de la Cuenca Urbana de la Quebrada El Batán: Quito-Ecuador. In Congreso Interamericano de Ingeniería Sanitaria y Ambiental (AIDIS) (pp. 1-12). Monterrey.

[39] Landázuri, A. C., Villarreal, J. S., Núñez, E. R., Pico, M. M., Lagos, A. S., Caviedes, M., \& Espinosa, E. (2018). Experimental evaluation of crushed Moringa oleifera Lam. seeds and powder waste during coagulation-flocculation processes. Journal of Environmental Chemical Engineering, 6(4), 5443-5451. 